\title{
Effect of Heat Treatment on Changes in Acid Phosphatase Activity during Tomato Ripening
}

\author{
Yasuyuki ShiraI, Takahide Sato, Nagao Ogura, \\ and Hiroki NaKagawA \\ Department of Agricultural Chemistry, Faculty of Horticulture, \\ Chiba University, Matsudo, Chiba 271, Japan
}

Received September 29, 1983

\begin{abstract}
Acid phosphatase (APase) activity of mature green tomatoes decreased during storage at $22^{\circ} \mathrm{C}$. Heat-treated tomatoes stored at $33^{\circ} \mathrm{C}$ showed a rapid decrease in APase activity, and failed to ripen. When heat-treated tomatoes were transferred to $22^{\circ} \mathrm{C}$ storage, APase activity increased. For most of the storage period (Day 10 excepted), activity of APase II was higher than that of APase I.

Changes in the level of APase II during the storage were estimated using rocket immunoelectrophoresis. Decrease in the specific activity of APase II was observed by the rocket height during storage at 22 and $33^{\circ} \mathrm{C}$; it declined more rapidly at $33^{\circ} \mathrm{C}$. The specific activity of this APase increased when the heat-treated tomatoes were transferred to $22^{\circ} \mathrm{C}$ storage.
\end{abstract}

Acid phosphatase (orthophosphoric-monoester phosphohydrolase, EC 3.1.3.2) activity has been reported to increase in the climacteric period in the fruits of apple, ${ }^{1)}$ mango, ${ }^{2)}$ banana $^{3 \sim 5)}$ and avocado ${ }^{6}$ before ripening. However, the APase activity of mature green tomatoes decrease upon storage at room temperatures before the fruits begin to ripen. ${ }^{7,8)}$ Heat treatment decreased the APase activity but failed to ripen the tomatoes; when the heat-treated fruits were transferred to $22^{\circ} \mathrm{C}$, APase activity increased ${ }^{8)}$ Storage life of the tomatoes could be extended greatly. ${ }^{9)}$

We have not determined if the change in APase activity can be attributed to a change in the amount of APase protein, or to activation or inactivation of preformed protein. Here, we study activity levels of APase in relation to ripening and enzyme concentration, by immunological techniques.

In this paper we show that the change of APase activity during ripening is due mainly to a change in APase II activity. There was a rapid decline in the specific activity of APase II judging by rocket height when the tomatoes were stored at $33^{\circ} \mathrm{C}$. The specific activity of
APase II, increased when heat-treated tomatoes were transferred to $22^{\circ} \mathrm{C}$ storage.

\section{MATERIALS AND METHODS}

Plant materials. Tomatoes (Lycopersicon esculentum cv. Ohgata Zuikoh) were harvested at the mature green stage at the experimental farm of the Faculty of Horticulture of Chiba University, and stored at either 22 or $33^{\circ} \mathrm{C}$. Those stored at $33^{\circ} \mathrm{C}$ were transferred to $22^{\circ} \mathrm{C}$ storage after the tenth day.

Preparation of APase I and II. APases were extracted from $200 \mathrm{~g}$ of tomato pericarp at about $4^{\circ} \mathrm{C}$ with $200 \mathrm{~mm}$ Tris- $\mathrm{HCl}(\mathrm{pH} 8.0)$, and precipitated with ammonium sulfate $(80 \%)$. After $10 \mathrm{~min}$ the precipitate was dissolved in small amount of $50 \mathrm{~mm}$ Tris- $\mathrm{HCl}(\mathrm{pH} 7.4)$ and applied to a DEAE-cellulose column $(1 \times 10 \mathrm{~cm})$ equilibrated beforehand with $50 \mathrm{~mm}$ Tris- $\mathrm{HCl}(\mathrm{pH} 7.4)$. Two major peaks of APase activity were detected. One was adsorbed to the column (APase II), and the other not (APase I) ${ }^{10)}$ APase II was eluted with $100 \mathrm{ml}$ of $500 \mathrm{~mm} \mathrm{NaCl}$ in $50 \mathrm{~mm}$ Tris$\mathrm{HCl}(\mathrm{pH} 7.4)$.

Measurement of APase activity. APase activity was monitored by estimating the $p$-nitrophenol liberated from $p$-nitrophenylphosphate according to the method of Bergmeyer. ${ }^{11)}$ One unit of enzyme activity is defined here as the amount of enzyme which forms $1 \mu \mathrm{mol}$ of $p$ nitrophenol per min at $30^{\circ} \mathrm{C}$.

* CRM, immunologically cross-reactive material. 
Antiserum to APase II. An antiserum against tomato APase II was prepared as described elsewhere. ${ }^{12)}$

Double immunodiffusion analysis. Double immunodiffusion was carried out according to the method of Ouchterlony. ${ }^{13)}$

Immunochemical assay of APase II. Changes in levels of APase II CRM* during storate of the tomatoes were estimated using rocket immunoelectrophoresis. ${ }^{14)}$ Agarose gel $(1 \% \mathrm{w} / \mathrm{v})$ containing $25 \mathrm{~mm}$ Tris- $\mathrm{HCl}$ buffer, $\mathrm{pH} 8.6$, and $1 \% \mathrm{v} / \mathrm{v}$ of crude antiserum was cast in a slab gel form $(10 \mathrm{~cm} \times 10 \mathrm{~cm} \times 1 \mathrm{~mm})$ and placed on a glass plate. Wells $3 \mathrm{~mm}$ diameter were cut and filled with $2 \mu \mathrm{l}$ of antigen containing 0.5 unit of APase activity. Electrophoresis was carried out to estimate the relative amounts of APase II CRM in the extracts, (which were adjusted to the same APase activity of 0.5 unit) of various ripening stages of the tomato, at $20 \mathrm{~V}$ for $24 \mathrm{hr}$ at $4^{\circ} \mathrm{C}$ on a flat bed apparatus with $25 \mathrm{~mm}$ Tris- $\mathrm{HCl}, \mathrm{pH} 8.6$, as running buffer. The antigen-antibody complex was stained for APase activity according to the method of Sahulka. ${ }^{15)}$ Since the APase II used in this experiment was not pure, results are expressed here in relative amounts with APase of the extracts taken as reference. The specific activity of APase II was not expressed in terms of protein, but rather as the reciprocal of its amount of CRM measured with anti APase II.

\section{RESULTS AND DISCUSSION}

\section{Changes in APase activity in tomato during storage at various temperatures}

Results are given in Fig. 1. Preliminary experiments confirmed that APase activity decreased rapidly during storage at $33^{\circ} \mathrm{C}$. However, after tomatoes stored at $33^{\circ} \mathrm{C}$ for 10

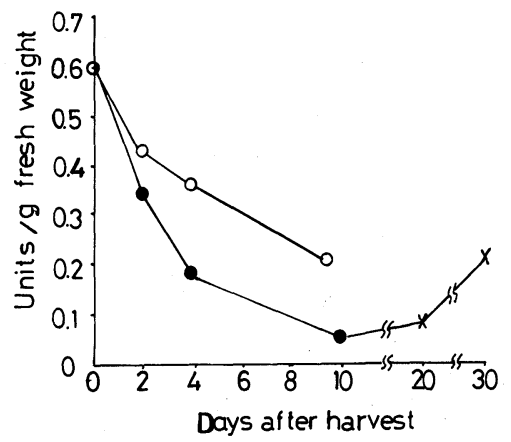

FIG. 1. Effect of Heat Treatment on Changes in Tomato APase Activity.

Mature green tomatoes stored at $22^{\circ} \mathrm{C}(\mathrm{O})$; at $33^{\circ} \mathrm{C}(\mathrm{O})$; pre-treated at $33^{\circ} \mathrm{C}$ for 10 days and then stored at $22^{\circ} \mathrm{C}$ $(x)$. days were transferred to $22^{\circ} \mathrm{C}$, APase activity increased.

The level of APase II activity adsorbed to the DEAE-cellulose column was much more than that of the nonadsorbed APase I during the ripening of tomatoes at $22^{\circ} \mathrm{C}$ (Fig. 2).

Changes in APase activity were mainly due to changes in APase II activity (Figs. 2 and 3).

\section{Double immunodiffusion analysis}

Earlier immunological studies showed that APase II did not share an antigenic determinant with APase I. ${ }^{12)}$ Therefore, we tried to

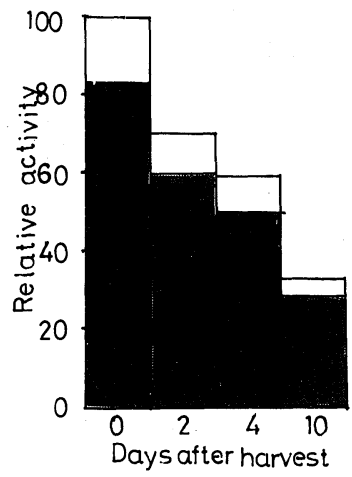

FIG. 2. Changes in APase I and II Activity of Tomatoes during Storage at $22^{\circ} \mathrm{C}$.

APase I and II were prepared by the method described elsewhere. ${ }^{10)}$ Amounts of APase II are indicated by shading.

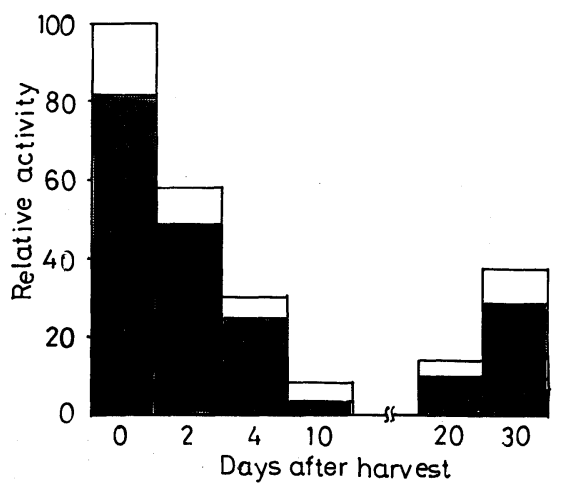

FIG. 3. Changes in APase I and II Activity of Tomatoes during Storage first at $33^{\circ} \mathrm{C}$ and then at $22^{\circ} \mathrm{C}$.

Mature green tomatoes were pre-treated at $33^{\circ} \mathrm{C}$ for 10 days and then stored at $22^{\circ} \mathrm{C}$. Apase I and II were prepared by the method described previously. ${ }^{10)}$ Amounts of APase II are indicated by shading. 
study the mechanism of changes in APase II activity during the ripening process, using antiserum to APase II. Results of the double immunodiffusion analysis (Fig. 4) suggest that

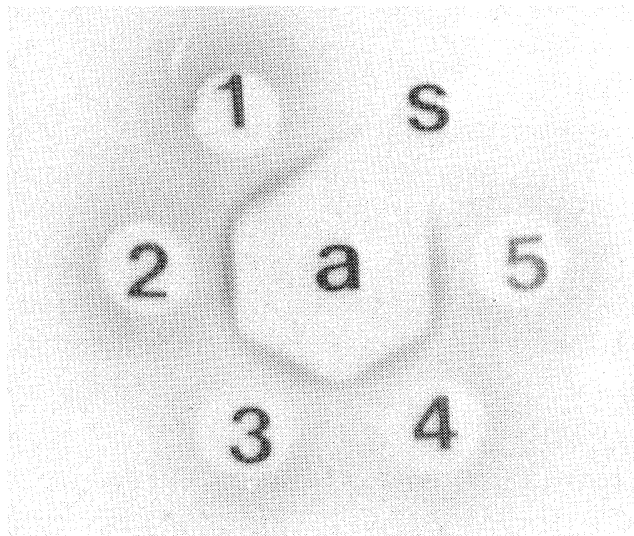

FIG. 4. Demonstration of Antiserum to Tomato APase II by Ouchterlony Double Diffusion.

Twenty-microliter wells were cut in the agar. Antiserum was put in the center well, and the others were filled with samples of APase II from tomatoes as shown: mature green (Well 1), stored at $33^{\circ} \mathrm{C}$ for 4 days (Well 2), stored at $33^{\circ} \mathrm{C}$ for 10 days (Well 3), stored at $33^{\circ} \mathrm{C}$ for 10 days and then at $22^{\circ} \mathrm{C}$ for 6 days (Well 4), stored at $33^{\circ} \mathrm{C}$ for 10 days and then at $22^{\circ} \mathrm{C}$ for 16 days (Well 5). In the $\mathrm{S}$ well is $0.9 \%$ $\mathrm{NaCl}$ in $10 \mathrm{~mm}$ Tris- $\mathrm{HCl}(\mathrm{pH} 7.0)$.

APase II activity was 0.9 unit. After development at $4^{\circ} \mathrm{C}$ for several days, precipitation bands stained using the method of Sahulka. ${ }^{14}$ samples of APase II from different stages of ripening have identical immunological properties.

\section{Immunochemical assay of APase II}

APase II activity in tomatoes decreases with increasing storage time (Fig. 1). This decrease in enzyme activity may be due to a decrease in the amount of APase II per cell, to qualitative modification of the enzyme, or to the progressive formation of APase II inhibitor. The last possibility is unlikely, because mixing experiments failed to demonstrate the formation of either an enzyme inhibitor or activator. Enzyme preparations for different stages of ripening were applied into wells in rocket immunoelectrophoresis gels. The procedure proved to be well quantitated (Fig. 5) and reproducible. Since the same amount of APase was deposited, an increase in the height of the peak would reflect an increase in the amount of CRM with APase II. Tables I and II show that the amount of APase II CRM in 0.5 unit of APase II increases during storage at 22 or $33^{\circ} \mathrm{C}$. A decrease was observed in the specific activity of APase II on the basis of rocket height during storage at these two temperatures. This decline in specific activity indicates a more rapid loss of active sites than of

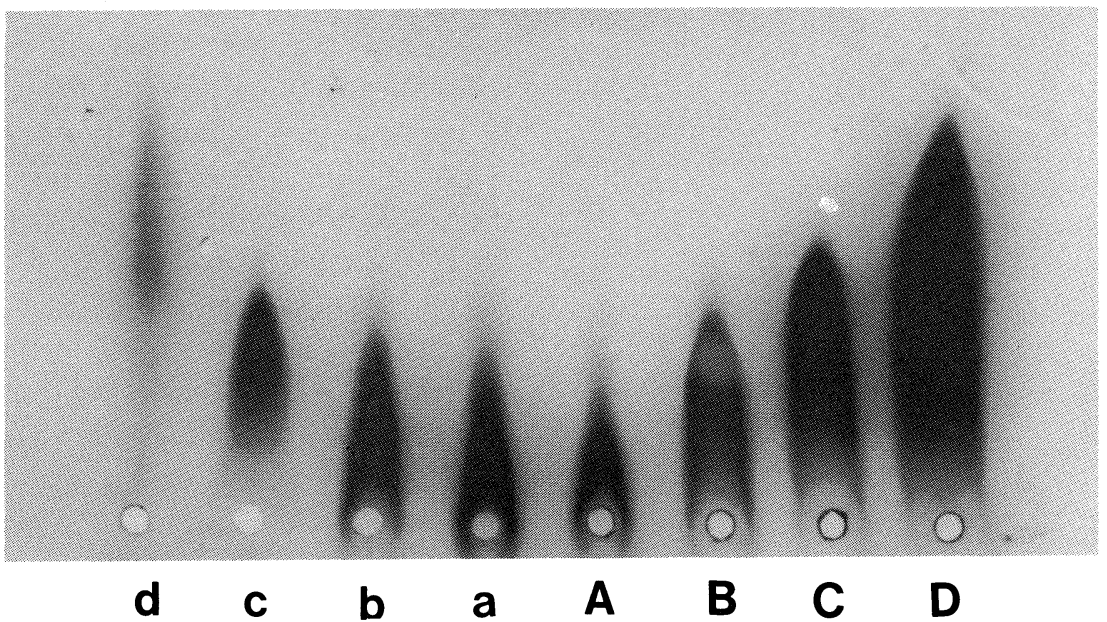

FIG. 5. Rocket Immunoelectrophoresis of APase II.

APase II applied to Wells A, B, C, and D amounted to $0.35,0.7,1.4$ and 2.8 units, respectively. The same amount of APase II ( 0.5 unit) of Day $0,2,4$, and 10 extracts from tomatoes stored at $33^{\circ} \mathrm{C}$ were applied to Wells a, b, c, and d, respectively. 
Table I. Changes in the Amount of APase II CRM and the Level of Specific Activity in Tomatoes during Storage at $22^{\circ} \mathrm{C}$

Levels of CRM were estimated using APase II fractions of tomatoes at various stages of ripening (days at $22^{\circ} \mathrm{C}$ ) by the immunological procedure described in the text.

\begin{tabular}{ccc}
\hline $\begin{array}{c}\text { Ripening stage } \\
\text { of the } \\
\text { tomatoes }\end{array}$ & $\begin{array}{c}\text { Relative amount } \\
\text { of APase II } \\
\text { CRM* }\end{array}$ & Specific activity \\
\hline $\begin{array}{c}\text { (days after } \\
\text { harvest) }\end{array}$ & & $\begin{array}{c}\text { 1/relative } \\
\text { amount of CRM }\end{array}$ \\
0 & 1.00 & 1.00 \\
2 & 1.37 & 0.73 \\
4 & 1.62 & 0.61 \\
10 & 2.46 & 0.41 \\
\hline
\end{tabular}

* In 0.5 units of APase II fractions.

Table II. Effect of Fluctuations BetweEn $33^{\circ} \mathrm{C}$ and $22^{\circ} \mathrm{C}$ ON Changes in the Amount of CRM against Anti APase II Serum and on SPECIFIC ACTIVITY OF APase II DURING RIPENING OF TOMATOES

Mature green tomatoes were pre-treated at $33^{\circ} \mathrm{C}$ for 10 days and then transferred to $22^{\circ} \mathrm{C}$. The levels of CRM were estimated in APase II fractions of tomatoes at various stages of ripening by the immunological procedure described in the text. Parentheses shows tomatoes stored at $33^{\circ} \mathrm{C}$ were transferred to $22^{\circ} \mathrm{C}$ storage after the tenth day.

\begin{tabular}{ccc}
\hline $\begin{array}{c}\text { Ripening stage } \\
\text { of the } \\
\text { tomatoes }\end{array}$ & $\begin{array}{c}\text { Relative amount } \\
\text { of APase II } \\
\text { CRM* }^{*}\end{array}$ & Specific activity \\
\hline $\begin{array}{c}\text { (days after } \\
\text { harvest) }\end{array}$ & & $\begin{array}{c}\text { 1/relative } \\
\text { amount of CRM }\end{array}$ \\
0 & 1.00 & 1.00 \\
2 & 1.42 & 0.70 \\
4 & 2.29 & 0.43 \\
10 & 5.83 & 0.17 \\
$(20)$ & 5.10 & 0.19 \\
$(30)$ & 1.86 & 0.54 \\
\hline
\end{tabular}

* In 0.5 units of APase II fractions.

immunological recognition sites. The results strongly indicate that the population of APase II molecules consists of some fully active molecules and a large amount of altered inactive molecules in tomatoes stored at both 22 and $33^{\circ} \mathrm{C}$ for 10 days. In a first step, we have found
APase II molecules which are catalytically inactive but immunologically active.

The formation of altered enzyme protein molecules is not improbable in higher plants or in other organisms. ${ }^{16 \sim 18)}$ Wittenback showed a decrease in ribulose-biphosphate-carboxylase specific activity during dark-induced senescence of wheat seedlings. ${ }^{19)}$ Small and Wray demonstrated an age-dependent conversion of nitrate reductase to cytochrome $c$ reductase species in barley leaf extracts. ${ }^{20)}$ At the senescent stage of tomatoes, we have already found $\beta$-fructofuranosidase which is catalytically inactive but immunologically active. ${ }^{21)}$

APase II activity of tomatoes decreased during storage at $33^{\circ} \mathrm{C}$. However, after their transfer to $22^{\circ} \mathrm{C}$, APase II activity increased as the fruit aged (Figs. 1 and 2). The specific activity of APase II also increased during the development of APase activity (Table II). It is probable that the increases in both the activity and specific activity of APase II is caused by an increase in the number of active APase II molecules per cell by de novo synthesis or activation of preformed inactive protein during the storage of the heat-treated tomatoes. When such tomatoes were transferred to room temperature, increase not only in APase activity $^{8)}$ but also in ethyrene production and respiration rate were observed. ${ }^{22}$ The role of APase in the tomato is still unclear. It would be interesting to examine the enzymatic properties of APase II present both in mature green tomatoes and in tomatoes held at $33^{\circ} \mathrm{C}$ for 10 days and transferred to $22^{\circ} \mathrm{C}$.

This paper presents evidence for enzyme alteration by heat treatment in tomatoes. The mechanism by which APase II is altered by heat treatment is not yet known. Recently Yoshioka et al. have studied the effect of heat treatment on APase activity ${ }^{5)}$ and protein synthesis $^{23)}$ in bananas. Banana preincubated for 5 days at $40^{\circ} \mathrm{C}$ did not have increased APase activity, and the fruit never ripened. This was attributed to a decrease in protein synthesis caused by the high temperature.

Accumulation of more information on these 
phenomena using purified enzyme preparations from fruit and vegetables may facilitate the understanding of the mechanisms of senescence and heat stress in the higher plants.

Acknowledgments. This work was supported in part by a Grant-in-Aid from the Agricultural Chemical Research Foundation and the Matsushima Foundation for the Advancement of Horticultural Science in Japan. The authors wish to express thanks to Professor Manocher of Brock University, Canada, for reading the manuscript.

\section{REFERENCES}

1) M. Rhodes and C. Wooltorton, Phytochemistry, 6, 1 (1967).

2) A. K. Mato, V. V. Modi and V. V. R. Raddy, Ind. J. Biochem., 5, 111 (1968).

3) De Leo and J. A. Sacher, Plant Physiol., 46, 208 (1970).

4) J. A. G. Areas and F. M. Lajolo, J. Food Biochem., 5, 19 (1981).

5) H. Yoshioka, Y. Ueda and K. Chachin, Nippon Shokuhin Kogyo Gakkaishi, 27, 511 (1980).

6) J. A. Sacher, Ann. Rev. Plant Physiol., 24, 197 (1973).

7) N. Ogura, R. Iwashita, S. C. Chen, H. Nakagawa and H. Takehana, Bull. Fac. Hort. Chiba Univ., 20, 67 (1972).

8) N. Ogura, T. Ishii and H. Nakagawa, Bull. Fac. Hort. Chiba Univ., 27, 9 (1980).

9) N. Ogura, H. Nakagawa and H. Takehana, Nippon
Nôgeikagaku Kaishi, 49, 189 (1975).

10) S. C. Chen, N. Ogura, H. Nakagawa and H. Takehana, Agric. Biol. Chem., 39, 2069 (1975).

11) H. V. Bergmeyer, "Methods of Enzymatic Analysis," Vol. 4, Verlag Chemie Weinheim and Academic Press, Inc., New York and London, 1974, p. 495.

12) A. Ozutsumi, T. Sato, N. Ogura and H. Nakagawa, Agric. Biol. Chem., 47, 1137 (1983).

13) O. Ouchterlony, Acta Pathol. Microbiol. Scand., 32, 231 (1953).

14) B. Weeke, "A Manual of Quantitative Immunoelectrophoresis: Methods and Applications," Scand. J. Immunol., 2, Suppl. 1; Universitetsforlaget, Oslo, 1973, p. 37.

15) J. Sahulka, Biologia Plantarum, 11, 442 (1969).

16) B. L. Strehler, "Time, Cells and Aging," Academic Press, New York, 1977.

17) A. Z. Reznick, L. Lavine, H. E. Gershon and D. Gershon, FEBS Lett., 128, 221 (1981).

18) S. Pontremoli, E. Melloni, M. Michetti, F. Salamino, B. Sparatora and B. C. Horecker, Proc. Natl. Acad. Sci. U.S.A., 79, 5194 (1982).

19) V. A. Wittenbach, Plant Physiol., 62, 604 (1978).

20) J. Brown, I. S. Small and J. L. Wray, Phytochemistry, 20, 389 (1981).

21) H. Nakagawa, K. Iki, M. Hirata, S. Ishigami and N. Ogura, Phytochemistry, 19, 195 (1980).

22) N. Ogura, R. Hayashi, T. Ogishima, Y. Abe, H. Nakagawa and H. Takehana, Nippon Nôgeikagaku Kaishi, 50, 519 (1976).

23) H. Yoshioka, Y. Ueda and K. Chachin, Nippon Shokuhin Kogyo Gakkaishi, 27, 610 (1980). 